\title{
Endogenous mediators of growth
}

\author{
BY NIGEL LOVERIDGE, COLIN FARQUHARSON \\ AND BEN A. A. SCHEVEN*
}

Bone Growth and Metabolism Unit, Rowett Research Institute, Bucksburn, Aberdeen A B2 9SB

Growth comprises three separate components; whole-body growth, tissue turnover and repair, and last, the response to external stimuli. Whole-body growth can be divided into changes associated with muscle, skin, viscera and skeleton. Because of our interest in bone metabolism the present review will concentrate on the processes associated with skeletal growth, turnover, and response to external stimuli. Although some of the factors which will be discussed are specific to bone the majority affect other body tissucs.

There are too many endogenous mediators of growth to list in a review such as this. Basically such mediators can be divided into two groups (Table 1), those which have a systemic action such as growth hormone $(\mathrm{GH})$ and those which act locally such as the transforming growth factors (TGF). Of those systemic factors, some such as GH have a general effect on a number of tissues. However, there are also systemic factors such as gonadotropins and ACTH which have trophic actions on particular target organs. Endogenous mediators of growth are varied as well as numerous. For instance. calcium can be considered a growth mediator for the parathyroid gland as prolonged hypocalcaemia results in a hypertrophy of the parathyroid gland.

Bone growth and metabolism rely on the action of a number of factors affecting the proliferation and differentiation of the major bone cell types and modulating their activity. The skeleton serves a structural role, but it is also responsible for maintaining normocalcaemia. These two functions may occasionally be contradictory but the primary role is the maintenance of serum $\mathrm{Ca}$ and at times of $\mathrm{Ca}$ stress (e.g. pregnancy and lactation) this occurs at the expense of skeletal integrity. Therefore, skeletal growth and metabolism are governed by two series of factors; those which control skeletal growth (e.g. GH and insulin-like growth factor-1 (IGF-1)) and the calciotropic hormones (parathyroid hormone (PTH), calcitonin and 1,25-dihydroxycholecalciferol $\left.\left(1,25(\mathrm{OH})_{2} \mathrm{D}_{3}\right)\right)$. It is becoming apparent that there is some overlap between these two systems as PTH, which at low levels is considered to be anabolic to the skeleton (Parsons et al. 1975), has recently been shown to increase the production of IGF-1 in bone cells (Canalis et al. 1989; Linkhart \& Mohan, 1989).

The control of bone growth and metabolism is dependent on the activity and interactions of particular cell types. These include the growth plate chondrocytes which are primarily responsible for longitudinal growth. The two cell types which are responsible for the turnover and repair of the skeleton are the osteoblasts which form bone and osteoclasts which resorb bone. This remodelling process is also important in intramembranous (skull growth) and endochondral bone formation during bone development and growth. The osteocyte, which is an osteoblast embedded in the matrix, is probably responsible for sensing the changes in mechanical demand (Pead et al. 1988).

* Present address: Academisch Ziekenhuis Utrecht, Post Box 8550(), 3508 GA Utrecht. The Netherlands. 
Table 1. Some examples of the various types of endogenous mediators of growth

\begin{tabular}{cl}
\hline Systemic & \\
(a) General & Growth hormone (GH) \\
& Insulin-like growth factors (IGF) \\
& Epidermal growth factor \\
& Thyroid hormones \\
& Insulin \\
& Gonadotropins \\
(b) Organ specitic & Thyroid-stimulating hormone \\
& Adrenocorticotrophin \\
& Calcium \\
& Insulin-like growth factors (IGF) \\
& Transforming growth factors (TGF) \\
& Platelet-derived growth factor \\
& Epidermal growth factor \\
& Osteoclast growth factor (OGF) \\
& Interleukins \\
\hline
\end{tabular}

\section{LONGITUDINAL BONE GROWTH}

The characteristic histological features of the long bones are developmentally regulated. At birth the columnar structure of the epiphyseal growth plate is incompletely formed. As a laminar organization of chondrocytes develops in the distal direction (Sissons, 1961) there is a uniformly distributed cell layer consisting of cells which rarely divide (Kember, 1978), which is termed the germinal layer. During longitudinal growth these cells differentiate and enter the proliferative layer where the cells multiply before maturing into hypertrophic chondrocytes. These cells produce the cartilaginous matrix which subsequently becomes calcified before being resorbed and replaced by ostcoblastmediated bone formation (Isaksson et al. 1987). Thus, longitudinal growth results from the increased production of cells and their subsequent expansion.

Post-natal longitudinal bone growth is primarily dependent on $\mathrm{GH}$, but while effects of $\mathrm{GH}$ are easily recognized, the site and cellular mechanisms behind these effects are unclear. Salmon \& Daughaday (1957) postulated that response to GH was mediated through the hepatic production of somatomedins, now termed insulin-like growth factors (IGF). This is based on the fact that addition of $\mathrm{GH}$ to explanted cartilage fragments produces little effect on metabolism. However, addition of serum stimulated a number of cellular functions associated with proliferation and differentiation. Serum from hypophysectomized animals had a lesser effect but subsequent GH therapy resulted in a serum with normal growth-promoting activities. The structure of both IGF has been elucidated (Rinderknecht \& Humbel, 1978a,b) and the genes encoding these factors characterized (Jansen et al. 1983, 1985).

However, Schoenle et al. (1982) infused high doses of purified IGF-1 into hypophysectomized rats but could only induce a slight increase in bone growth which was of a similar magnitude to that induced by GH alone. Similarly, in a study using recombinant IGF-1, high doses had to be used to induce bone growth, while GH was more effective at a fiftyfold lower dose (Skottner et al. 1987). It is now apparent that while administration of 
large doses of IGF-1 significantly increases body-weight, it produces only small effects on longitudinal bone growth.

To examine the possibility that $\mathrm{GH}$ might have a direct cffect on the growth plate. Isaksson and colleagues (Isaksson et al. 1982: Isgaard et al. 1986; Nilsson et al. 1987) infused low concentrations of $\mathrm{GH}(50 \mathrm{ng} / \mathrm{d})$ directly into the growth plate or into the knee joint and showed that it stimulated longitudinal growth compared with the contralateral limb. IGF-1 was also capable of stimulating epiphyseal cartilage width but a combination of the two growth promoters produced no additional increase in bone growth. Other groups have confirmed much of this work (Russell \& Spencer, 1985; Schlecter et al. 1986).

These studies have been supported by the findings that many tissues produce IGF-1 (D'Ercole et al. 1984) and has led to the development of an alternative concept of GH action whereby $\mathrm{GH}$ has a direct effect on peripheral tissues which in turn mediate the effect by the local production of IGF-1 (Underwood et al. 1986). Many of the organ-specific growth mediators outlined in Table 1 have been shown to stimulate the local production of IGF-1 and IGF-1 may in turn potentiate the response to those growth mediators (for review, see Holly \& Wass, 1989). One of the important questions for future research is whether the direct or indirect actions of $\mathrm{GH}$ on peripheral tissues are physiological and what is the relative contribution of each pathway to the final effect.

\section{BINDING PROTEINS}

Both GH and IGF are either found free or complexed to binding proteins within the circulation. Human plasma is known to contain at least two binding proteins $(>100 \mathrm{~K}$ and $80-8.5 \mathrm{~K}$ ) for growth hormone each with varying degrees of affinity for human $\mathrm{GH}$ (Baumann et al. 1986; Herington et al. 1986). The high affinity peak (80-85 K) is responsible for $80-90 \%$ of the complexed GH (Baumann et al. 1989). Under physiological conditions approximately $50 \%$ and $29 \%$ of the circulating $22 \mathrm{~K}$ and $20 \mathrm{~K}$ human $\mathrm{GH}$ respectively are in a complexed form (Baumann et al. 1988). At $\mathrm{GH}$ concentrations greater than about $20 \mathrm{ng} / \mathrm{ml}$ the complexed fraction declines in a concentration dependent manner due to partial saturation of the binding protein (Baumann et al. 1988).

The concentrations of both binding proteins vary considerably from subject to subject in health and disease but are grossly maintained within the normal range in a number of diverse conditions which are known to result in abnormal $\mathrm{GH}$ levels such as acute infection, liver cirrhosis, acromegaly, uraemia (Baumann et al. 1989). The levels of binding protein were, however, significantly lower in neonates but reached the adult levels by 1 year of age (Baumann et al. 1989). Limited evidence exists that the two binding proteins are differentially regulated with the larger binding protein $(>100 \mathrm{~K})$ having sex hormone dependency but not the high-affinity binding protein $(80-85 \mathrm{~K})$.

More than $98 \%$ of plasma IGF-1 and IGF-2 is bound to a $150 \mathrm{~K}$ complex whose concentration is $\mathrm{GH}$ dependent (Baxter \& Martin, 1986). Acidification results in an acid-stable subunit of $50 \mathrm{~K}$ with a binding site with equal high affinity for either IGF-1 or IGF-2 (Martin \& Baxter, 1986).

A group of smaller binding proteins $(25-43 \mathrm{~K})$ are also present in serum and one of these $(26 \mathrm{~K})$ is found in amniotic fluid (Povoa et al. 1984). The serum levels of this protein are low in acromegaly and raised in hypopituitarism so it is believed to be 
inversely related to $\mathrm{GH}$ (Drop et al. 1984). Injection of GH to GH-deficient patients resulted in a fall in the level of binding protein (Busby et al. 1988), although it has been reported that the levels rise during the nocturnal increase in GH secretion (Baxter \& Colwell, 1987). Studies on nutritional influences on this protein have shown that its concentration falls after a meal (Baxter \& Colwell, 1987; Busby et al. 1988) and rises during overnight fasting (Busby et al. 1988) and during the infusion of glucose and insulin (Sukkari et al. 1988).

As the IGF- and GH-binding proteins have only recently been characterized the role of such binding proteins in the expression of the biological activity of these growth promoters is as yet unclear. One function that has been attributed to them is to protect GH (Baumann et al. 1987) and IGF (Cohen \& Nissley, 1976) from degradation and prolonging their biological half-life by restricting their access to degradation sites. A number of other functions have speculatively been attributed to the GH-binding protein. These include inhibition of $\mathrm{GH}$ action by interference with $\mathrm{GH}$-receptor binding, enhancement of $\mathrm{GH}$ action by acting as a cofactor for receptor binding or acting as a circulating hormone reservoir during periods of fluctuations in GH secretion (Baumann et al. 1987). Similarly, inhibition (Drop et al. 1979; Zapf et al. 1979: Knauer \& Smith, 1980) or enhancement (Clemmons et al. 1986; Elgin et al. 1987) of the activity of IGF-1 has been attributed to the low-molecular-weight IGF-binding proteins. The $150 \mathrm{~K}$ IGF-binding protein is considered due to its very long half-life (Hodgkinson et al. 1987) to constitute an IGF storage compartment.

The presence of these binding proteins has undoubtedly important implications in the metabolism, distribution and physiological activity of $\mathrm{GH}$ and the IGFs but these processes are as yet unclear and warrant further research.

\section{LOCAL TURNOVER AND REPAIR}

The activity of osteoblasts and osteoclasts is closely coupled (Rodan \& Martin, 1981) which results in skeletal turnover without accretion or loss. Both the activity and the proliferation and differentiation of bone cells appear to be under the control of a number of growth factors. The bone matrix itself is a storehouse for a plethora of factors which can induce bone formation. In the 1960s, Marshall Urist (1965) showed that devitalized bone was capable of inducing endochondral bone formation. Several groups have pursued this line of research and have purified a number of growth factors (Reddi \& Anderson, 1976).

In addition to these bone specific growth factors there are other growth factors which have a more general activity and are also found within the bone matrix. These include IGF-2 (Mohan et al. 1988), fibroblast growth factor (Hauschka et al. 1986) which is mitogenic for mesoderm- and neuroectoderm-derived cells (Gospodarowicz et al. 1987) and TGF- $\beta$ (Sporn et al. 1987).

Work in our laboratory is concerned with two aspects of the control of bone cell activity. First the development of novel techniques which enable the in situ measurement of the biochemistry of bone cells (Bradbeer et al. 1988; Loveridge \& Farquharson, 1989), and second the purification of a factor relcased from osteoblasts which stimulates the proliferation and differentiation of osteoclasts (Dickson \& Scheven, 1989; Scheven et al. 1989). This factor affects the number of osteoclasts but not the activity of existing osteoclasts and has been termed osteoclast growth factor (OGF). 
TGF- $\beta$ is produced by osteoblasts in response to calciotropic hormones (Pfeilschifter \& Mundy, 1987) and inhibits bone resorption induced by other factors (Pfeilschifter et al. 1988), although in some systems it stimulates bone resorption (Tashjian et al. 1985). TGF- $\beta$ is produced as a latent precursor molecule which is then cleaved to release the biologically active TGF- $\beta$ (Sporn et al. 1987), a process of which the osteoclast is capable (Oreffo et al. 1989). In some but not all in vitro assays TGF- $\beta$ stimulates markers of bone formation such as osteoblastic alkaline phosphatase (EC 3.1.3.1) activity (Pfeilschifter et al. 1987). Thus, it has been suggested that TGF- $\beta$ acts as an anabolic coupling factor by stimulating formation and inhibiting resorption. In our laboratory, however, while TGF- $\beta$ inhibits osteoclastic activity it also inhibits osteoblastic activity (Loveridge \& Farquharson, 1989), although the latter action is about 100) times less sensitive.

\section{RESPONSE TO EXTERNAL STIMULI}

The last aspect of growth which we will discuss is the response to external stimuli. In the case of bone it is obvious that external stimuli such as dietary deficiencies of vitamin $\mathrm{D}$, changes in the availability of Ca or increased demand for Ca result in alterations in the Ca homeostatic mechanisms with a consequent loss of skcletal material. Similarly metabolic diseases such as diabetes can result in significant bone loss (Hui et al. 1985). What is less well characterized is the response to mechanical stress.

It is well known that the capacity of bone to remodel itself is influenced by the degree of mechanical loading. For instance, prolonged bed rest results in disuse ostcoporosis (Asher, 1947; Krolner \& Toft, 1983). Furthermore, short periods of mechanical stress in which the magnitude and distribution of the dynamic strains within the bone are different from those to which it is normally accustomed (Lanyon, 1984) result in profound changes in remodelling activity.

What is not clear at present is the mechanism of response to loading, although recent evidence suggests a possible role for the osteocyte (Pead et al. 1988).

\section{SUMMARY}

In the present review it is not possible to discuss the effects of the numerous endogenous mediators of growth. What we have attempted to do is to indicate the areas of controversy and the need for further rescarch. In our view, four main questions arise. First, what are the relative contributions of the direct and indirect effects of GH? Indeed. if $\mathrm{GH}$ can produce all its effects by local production of IGF, is the original somatomedin hypothesis still tenable? Second, how is the biological activity of the IGF modified by the presence of binding proteins? Because of the role of binding proteins in modulating IGF bioactivity, care must be taken when interpreting results from immunoassays for IGF because this will only represent the concentration of IGF not the level of biological activity, a situation which is analogous to that which pertains with certain polypeptide hormones (for review, see Robertson et al. 1987). Third, how are the activities of the osteoblast and osteoclast coupled so that in the mature adult, bone formation and bone resorption are roughly equivalent? Understanding of this process will undoubtedly involve the elucidation of the roles and interactions between a number of locally acting growth factors and systemic hormones and will lead to the understanding of certain metabolic bone diseases such as osteoporosis. Last, how is the response to local stimuli 
such as mechanical stress transduced? This is again probably dependent on the activity of local growth factors but may also involve changes in the interactions between bone cells and their underlying matrix components (Skerry et al. 1988).

\section{REFERENCES}

Asher, R. (1947). The dangers of going to bed. Lancet ii, 967-968.

Baumann, G., Amburn, K. D. \& Buchanan, T. A. (1987). The effect of circulating growth hormone-binding protein on metabolic clearance, distribution and degradation of human growth hormone. Journal of Chinical Endocrinology and Metabolism 64, 657-660.

Baumann, G., Amburn, K. \& Shaw, M. A. (1988). The circulating growth hormone (GH)-binding protein complex: A major constituent of plasma GH in man. Endocrinology 122, 976-984.

Baumann. G.. Shaw, M. A. \& Amburn, K. (1989). Regulation of plasma growth hormone-binding proteins in health and discasc. Metabolism 8, 683-689.

Baumann, G., Stolar, M. Amburn, K., Barsano, C. P. \& DeVries, B. C. (1986). A specific growth hormone binding protein in human plasma: initial characterization. Journal of Clinical Endocrinology and Metabolism 62, 134-141.

Baxter, R. C. \& Colwell, C. T. (1987). Diurnal variation of growth hormone dependent binding protein for insulin-like growth factors in human plasma. Journal of Clinical Endocrinology and Metabolism 65. 432-440.

Baxter, R. C. \& Martin, J. L. (1986). Radioimmunoassay of growth hormone-dependent insulin-like growth factor binding protein in human plasma. Journal of Clinical Investigation 78, 1054-1512.

Bradbeer, J. N., Dunham, J., Fischer. J. A., Nagant de Deuxchaisnes, C. \& Loveridge, N. (1988). The metatarsal cytochemical bioassay of parathyroid hormone: validation, specificity, and application to the study of pseudohypoparathyroidism type I. Journal of Clinical Endocrinology and Metabolism 67, $1237-1243$.

Busby, W. H., Snyder, D. K. \& Clemmons. D. R. (1988). Radioimmunoassay of a 26,000-dalton plasma insulin-like growth factor-binding protein: control by nutritional variables. Journal of Clinical Endocrinology and Metabolism 67, 1225-1230.

Canalis, E., Centrella, M., Burch, W. \& McCarthy, T. L. (1989). Insulin-like growth factor I mediates selective anabolic effects of parathyroid hormone in bone cultures. Journal of Clinical Investigaiton 83, 60-65.

Clemmons, D. R., Elgin, R. G., Han, V. K. M., Casella, S. J., D'Ercole, A. J. \& Van Wyk, J. J. (1986). Cultured fibroblast monolayers secrete a protein that alters the cellular binding of somatomedin-C/insulinlike growth factor I. Journal of Clinical Investigation 77, 1548-1556.

Cohen, K. L. \& Nissley, S. P. (1976). The serum half-life of somatomedin activity: evidence for growth hormone dependence. Acta Endocrinologica 83, 243-258.

Cornell, H. J., Enberg, G. \& Herington, A. C. (1987). Preferential association of the insulin-like growth factors $I$ and II with metabolically inactive and active carrier bound complexed in serum. Biochemical Journal 241, 745-750.

D'Ercole. A. J., Stiles, A. D. \& Underwood, L. E. (1984). Tissue concentrations of somatomedin C: Further evidence for multiple sites of synthesis and paracrine or autocrine mechanisms of action. Proceedings of the National Academy of Sciences, USA 81, 935-939.

Dickson, I. R. \& Scheven, B. A. A. (1989). Regulation of new osteoclast formation by a bone cell-derived macromolecular factor. Biochemical and Biophysical Research Communications 159, 1383-1390.

Drop, S. L. S., Kortleve, D. J. \& Guyda, H. J. (1984). Isolation of a somatomedin binding protein from preterm amniotic fluid: development of a radioimmunoassay. Journal of Clinical Endocrinology and Metabolism 59, 899-907.

Drop, S. L. S., Valiquette. G., Guyda, H. J., Corvol, M. T. \& Posner, B. I. (1979). Partial purification and characterisation of a binding protein for insulin-like activity (ILAs) in human amniotic fluid: a possible inhibitor of insulin-like activity. Acta Endocrinoligica (Copenhagen) 90, 505-518.

Elgin, R. G., Busby, W. H. \& Clemmons, D. R. (1987). An insulin-like growth factor (IGF) binding protein enhances the biological response to IGF-I. Proceedings of the National Academy of Sciences, USA 84, 3254-3258.

Gospodarowicz, D., Ferrara, N., Schwegerer, L. \& Nuefeld, G. (1987). Structural characterization and biological functions of fibroblast growth factor. Endocrine Reviews 8, 95-114. 
Hauschka, P. V., Mavrakos, A. E., Iafrati, M. D., Doleman, S. E. \& Klagsburn. M. (1986). Growth factors in bone matrix. Isolation of multiple types by affinity chromatography. Journal of Biological Chemistry 261, $12665-12674$.

Herington, A. C., Ymer, S. \& Stevenson, J. (1986). Identification and characterisation of specific binding proteins for growth hormone in normal sera. Journal of Clinical Investigation 77, 1817-1823.

Hodgkinson, S. C., Davis, S. T., Burleigh, B. D., Henderson, H. V. \& Gluckman, P. D. (1987). Metabolic clcarance of protein bound and free insulin-like growth factor-I in fed and starved sheep. Journal of Endocrinology 115, 233-240.

Holly, J. M. P. \& Wass, J. A. H. (1989). Insulin-like growth factors; autocrine, paracrine or endocrine? New perspectives of the somatomedin hypothesis in the light of recent developments. Journal of Endocrinology 122, 611-618.

Hui, S. L., Epstein, S. \& Johnston, C. C. Jr (1985). A prospective study of bone mass in patients with type I diabetes. Journal of Clinical Endocrinology and Metabolism 60, 74-79.

Isaksson, O. G. P., Jansson, J.-O. \& Gausev, I. A. M. (1982). Growth hormone stimulates longitudinal bone growth directly. Science 216, 1237-1239.

Isaksson, O. G. P., Lindahl, A., Nilsson, A. \& Isgaard, J. (1987). Mechanism of the stimulatory effect of growth hormone on longitudinal bone growth. Endocrine Reviews \$, 426-438.

Isgaard, J., Nilsson, A., Lindahl, A., Jansson, J.-O. \& Isaksson, O. G. P. (1986). Effects of local administration of GH and IGF-I on longitudinal bone growth in rats. American Journal of Physiology 250 , E367-E372.

Jansen, M., Van Schaik, F. M. A., Ricker, A. T., Bullock, G., Woods, D. E., Gabbay, K. H., Nussbaum, A. L., Sussenbach, J. S. \& Van Den Brande, J. L. (1983). Sequence of a cDNA encoding human insulin-like growth factor I precursor. Nature 306, 609-611.

Jansen, M., Van Schaik, F. M. A., Von Tol, H., Van Den Brande, J. L. \& Sussenbach, J. S. (1985). Nucleotide sequence of cDNAs encoding precursors of human insulin-like growth factor II (IGF-II) and an IGF-II variant. FEBS Letters 179, 243-246.

Kember, N. F. (1978). Cell kinetics and the control of growth in long bones. Cell arid Tissue Kinetics 11. $477-485$.

Knauer, D. J. \& Smith, G. L. (1980). Inhibition of biological activity of multiplication stimulating activity by binding to its carrier protein. Proceedings of the National Academy of Sciences, USA 77, 7252-7256.

Krolner, B. \& Toft, B. (1983). Vertebral bone loss: unheeded side effect of therapeutic bed rest. Clinical Science 64, 537-540.

Lanyon, L. E. (1984). Functional strain as a determinant for bone remodelling. Calcified Tissue International 36, S56-S61.

Linkhart, T. A. \& Mohan, S. (1989). Parathyroid hormone stimulates release of insulin-like growth factor-I (IGF-I) and IGF-II from neonatal mouse calvaria in organ culture. Endocrinology 125, 1484-1491.

Loveridge, N. \& Farquharson, C. (1989). A novel approach to the assay of the skeletal activities of growth factors and calciotropic hormones. Journal of Bone and Mineral Research 4, S286 Abstr.

Martin, J. L. \& Baxter, R. C. (1986). Insulin-like growth factor-binding protein from human plasma. Journal of Biological Chemistry 261, 8754-8760.

Mohan, S., Jennings, J. C., Linkhart, T. A. \& Baylink, D. J. (1988). Primary structure of human skeletal growth factor: homology with human insulin-like growth factor-II. Biochimica et Biophysica Acta 966 , 44-55.

Nilsson, A., Isgaard, J., Lindahl, A., Peterson, L. \& Isaksson, O. G. P. (1987). Effects of unilateral arterial infusion of $\mathrm{GH}$ and IGF-I on tibial longitudinal bone growth in hypophysectomized rats. Calcified Tissue International 40, 91-96.

Orreffo, R. O. C., Mundy, G. R., Seyedin, S. M. \& Bonewald, L. F. (1989). Activation of the bone-derived latent TGF beta complex by isolated osteoclasts. Biochemical and Biophysical Research Communications 158, 817-823.

Parsons, J. A., Rafferty, B., Gray, D., Reit, B., Zanelli, J. M., Keutman, H. T., Tregear, G. W., Callahan, E. N. \& Potts, J. T. Jr (1975). Pharmacology of parathyroid hormone and some of its fragments and analogues. In Calcium Regulating Hormones, pp. 33-39 [R. V. Talmage. M. Owen and J. A. Parsons. cditors]. Amsterdam: Excerpta Medica.

Pead, M. J., Suswillo, R., Skerry, T. M., Vedi, S. \& Lanyon, L. E. (1988). Increased ${ }^{3} \mathrm{H}$ uridine levels in osteocytes following a single short period of dynamic bone loading in vivo. Calcified Tissue International $\mathbf{4 3}$ 92-96. 
Pfeilschifter, J., D'Souza, S. M. \& Mundy, G. R. (1987). Effects of transforming growth factor- $\beta$ on ostcoblastic osteosarcoma cells. Endocrinology 121, 212-218.

Pfeilschifter. J. \& Mundy, G. R. (1987). Modulation of type $\beta$ transforming growth factor activity in bone cultures by osteotropic hormones. Proceedings of the National Academy of Sciences, USA 84, 2024-2028.

Pfeilschifter. J.. Sevedin, S. M. \& Mundy, G. R. (1988). Transforming growth factor beta inhibits bone resorption in fetal long bone cultures. Journal of Clinical Investigation 82, 680-685.

Povoa, G., Enberg, G., Jornvall, H. \& Hall, K. (1984). Isolation and characterization of a somatomedinbinding protein from mid-term amniotic fluid. European Journal of Biochemistry 144, 199-204.

Reddi, A. H. \& Anderson. W. A. (1976). Collagenous bone matrix-induced endochondral ossification and hacmopoiesis. Journal of Cell Biology 69, 557-572.

Rinderknecht, E. \& Humbel, R. E. (1978a). The amino acid sequence of human insulin-like growth factor I and its structural homology with proinsulin. Journal of Biological Chemistry 253, 2769-2776.

Rinderknecht. E. \& Humbel, R. E. (1978h). Primary structure of insulin-like growth factor II. FEBS Letters $89,283-286$.

Robertson, W. R. Lambert, A. \& Loveridge, N. (1987). The role of modern bioassays in clinical endocrinology. Clinical Endocrinology 27, 259-278.

Rodan, (.. A. \& Martin, T. J. (1981). Role of osteoblasts in hormonal control of bone resorption. Calcified Tissue International 33, 349-351.

Russell, S. M. \& Spencer, E. M. (1985). Local injections of human or rat growth hormone or of purified human somatomedin C stimulate unilateral tibial epiphyseal growth in hypophysectomized rats. Endocrinology $116,256.3-2567$.

Salmon, W. D. Jr \& Daughaday, W. H. (1957). A hormonally controlled serum factor which stimulates sulfate incorporation by cartilage in vitro. Journal of Laboratory and Clinical Medicine 49, 825-836.

Scheven, B. A. A., Hamilton, N. J., Duncan, A. \& Robins, S. P. (1989). Osteoclast growth factors produced by fetal rat bone in vitro. Journal of Bone and Mineral Research 4, S285 Abstr.

Schlecter. N. L., Russell, S. M.. Spencer, E. M. \& Nicoll. C. S. (1986). Evidence to suggest that the direct growth promoting effects of growth hormone on cartilage in vivo are mediated by the local production of somatomedin. Proceedings of the National Academy of Sciences. USA 83, 7932-7934.

Schoenle. E., Zapf, J., Humbel, R. E. \& Froesch, E. R. (1982). Insulin-like growth factor I stimulates growth in hypophysectomized rats. Nature 296. 252-253.

Sissons, H. A. (1961). The growth of bone. In The Biochemistry and Physiology of Bone, pp. 443-474 [G. H. Bourne, editor]. New York: Academic Press.

Skerry, T., Bitensky, L., Chayen, J. \& Lanyon, L. E. (1988). Load-related reorientation of bone proteoglycan in vivo. Strain memory in bone tissue. Journal of Orthopaedic Research 6, 547-551.

Skottner, A.. Clark, R. G., Robinson, I. C. A. F. \& Fryklund, L. (1987). Recombinant human insulin-like growth factor: testing the somatomedin hypothesis in hypophysectomized rats. Journal of Endocrinology $112,123-132$.

Sporn, M. B., Roberts, A. B., Wakefield. L. M. \& de Crombrugghe, B. (1987). Some recent advances in the chemistry and biology of transforming growth factor-beta. Journal of Cell Biology 105, 1039-1045.

Sukkari, A. M., Koivisto. V. A., Rutanen, E. M., Jarvinen, H., Karonen, S. L. \& Seppala, M. (1988). Insulin regulates serum levels of low molecular weight insulin-like growth factor binding protein. Journal of Clinical Endocrinology and Metabolism 66, 266-272.

Tashjian. A. H., Vockel, E. F., Lazzaro, M., Singer, F. R.. Roberts, A. B.. Derynck. R., Winkler, M. E. \& Levine, L. (1985). $\alpha$ and $\beta$ human transforming growth factors stimulate prostaglandin production and bone resorption in cultured mousc calıaria. Proceedings of the National Academy of Sciences, LSA 82. $4535-4538$.

Underwood, L. E., D'Ercole, A. J., Clemmons, D. R. \& Van Wyk, J. J. (1986). Paracrine functions of somatomedins. In Clinics in Endocrinology and Metabolism: Paracrine Control, vol. 15. pp. 59-77 |P. Franchimont, editor]. London: W. B. Saunders Co.

Urist, M. (1965). Bone formation by autoinduction. Science 150, 893-899.

Zapf, J., Schocnle, E., Jagers. E.. Sand, I. \& Froesch, E. R. (1979). Inhibition of the action of non-suppressible insulin-like activity on isolated rat fat cells by binding to its carrier protein. Journal of Clinical Investigation 63, 1077-1084. 